\title{
Small Holders Managed Manure Nutrient Losses and Their Implications on Environment
}

\author{
N. A. Minase ${ }^{1, *}$, M. M. Masafu ${ }^{2}$, A. E .Geda ${ }^{1}$, A. T. Wolde ${ }^{1}$ \\ ${ }^{1}$ International Livestock Research Institute, Ethiopia \\ ${ }^{2}$ Department of Agriculture and Animal Health, University of South Africa, South Africa
}

Copyright $(\subset 2015$ by authors, all rights reserved. Authors agree that this article remains permanently open access under the terms of the Creative Commons Attribution License 4.0 International License

\begin{abstract}
Animal manure is rich in absorbable plant nutrients and an appropriate addition of manure into the soil respond to high crop productivity than use of commercial fertilizer. But volatilization of ammonia due to high temperature and leaching of nitrate, phosphorous and potassium into the soil due to rainfall results in the loss of manure nutrients. The objective of this study was to assess manure nutrient loss and gaseous emissions due to inappropriate manure management. The study was conducted in central Ethiopian highland, east of the capital Addis Ababa. The study included laboratory analysis for manure nutrients contents from sampled units and the manure management type was captured through focus group discussions. Storage age has impacted on nutrient losses as a result the highest loss of $\mathrm{N}, \mathrm{P}$ and $\mathrm{K}$ occurred in 2 to 3 years at the rate of $84 \%, 19 \%$ and $42 \%$, respectively. The analysis of variance showed that at $\mathrm{P}<0.05$, there was a significant difference in storage age for $\mathrm{N}$ and $\mathrm{K}$, but there was no significant difference for $\mathrm{P}$ across different storage ages. Shade type and manure heap height has no significant impact on nutrient losses. The total carbon equivalent $\left(\mathrm{CO}_{2} \mathrm{e}\right)$ gas emitted per household per annum was estimated at 11 , $276 \mathrm{~kg} \mathrm{CO}_{2}$ e (i.e. $8200 \mathrm{~kg} \mathrm{CO}_{2}$ e came from methane directly released by livestock plus their manure, $2694 \mathrm{CO}_{2} \mathrm{e}$ came from $\mathrm{N}_{2} \mathrm{O}$ emissions from manure management and 381.48 $\mathrm{kg} \mathrm{CO} 2 \mathrm{e}$ came from $\mathrm{CO}_{2}$ released from manure burning) that is about 2 tons $\mathrm{CO}_{2} \mathrm{e}$ per capita per year, twice the value reported for Ethiopia emission in 2005. The largest emissions were from methane $(72.6 \%)$, nitrous oxide $(24 \%)$ and carbon $(3.4 \%)$, this result appeal for a need to improve livestock and manure management systems under smallholders' agriculture in order to curb the challenges of global carbon release.
\end{abstract}

Keywords Green House Gas Emission; Livestock; Manure; Nutrient Loss; Smallholders

\section{Introduction}

Livestock production has several advantages under smallholder agriculture, but it is also the largest global source of methane emissions representing 20 to $25 \%$ of all sources of methane. In addition livestock is the greatest generator of nitrous oxide which contributes to global warming [12,17]. In addition to pollution, poorly managed livestock keeping is blamed for soil degradation through overgrazing, trampling and compaction [3].

Animal manure is more efficiently utilized by plants than commercial fertilizer because a larger fraction of nutrients from manure is absorbed by the plants $[2,6]$. However, their negative environmental consequence is eminent during the storage of manure in the open fields. In the case of open field manure storage operation volatilization of ammonia occur due to the high temperature and nitrate, phosphorous and potassium leach down due to high rainfall. Volatilization and leaching results to loss of nutrients making them inaccessible to plant root absorption. Mode of manure application during farming is also important to nutrient losses. For example, surface spread of manure without working it into the soil during periods of high precipitation on fallow land may also lead to volatilization, leaching and surface runoff of manure [2]. Even when nutrient levels in animal manure adjusted to the level of nutrient removal by the crop, wrong application techniques can cause losses or emissions [2]. Thus implies that manure management is more important than manure production.

Although manure remains an important organic source of fertilizer and energy, its impact on the environment has never been given adequate research it deserves, particularly under mixed-crop livestock production system [25]. The purpose of this study was, therefore, to document the impact of storage type and age of stored manure on the local environment under mixed crop-livestock production system of smallholders farming.

Research on manure use and management in the highlands of Ethiopia were carried out by Tesfaye et al [25]; and these authors have explained about manure storage type, means of manure transportation and the level manure use as soil fertilizer in the highland agro-ecology. However their report 
did not describe the impact of different manure management systems on the environment and their implication to local and global air pollution. Getente [7] reported the effect of manure and nitrogen fertilizer on the perennial grasses' establishment, herbage yield and seed production in that was conducted in the highland agro-ecology of Ethiopia. The National Meteorological Service Agency in Ethiopia [20] and Asres [1] undertook a greenhouse gas emissions inventory for all sources in Ethiopia based on the guideline of IPCC [13], including manure pollution at national level. However, theses authors did not oversee the effect of different manure management systems on the local environment and did not scaled down the influence at household level.

Thus the current study attempted to assess the different manure management systems and their impacts on the environment. The current research also addressed the following issues: to explore the extent of nutrients losses due to manure storage type and storage age and to document the household level gaseous emissions due to inappropriate manure management.

Information on these research questions was captured through focus group discussions and manure sampling to evaluate their chemical content in laboratory analysis.

Objectives: to determine manure nutrient loss and gaseous emissions due to different manure management practices.

\section{Materials and Methods}

\subsection{The Study Area}

The study area Ada'a district has a high potential for livestock- crop production systems. Livestock and crop production are integrated farm activities at household farm level as animal draught power is used for plowing, threshing, and transporting of agricultural goods and services. Animal manure is used as a fuel for household energy source and also utilized to improve soil fertility. Manure also sold on market as a means to generate income to smallholder farmers.

The study district is one of the 12 districts in East Shoa zone in Oromia regional state of Ethiopia. It is located southeast of the capital Addis Ababa at $38^{\circ} 51^{\prime}$ '43.63' to $39^{\circ} 04^{\prime} 58.59^{\prime \prime}$ 'E and $8^{\circ} 46^{\prime} 16.20^{\prime \prime}$ to $8^{\circ} 59^{\prime} 16.38^{\prime \prime}$ ' $\mathrm{N}$, on the western margin of the Great East African Rift Valley. The altitude ranges between 1500 to over 2000 meters above sea level. There are two major agro climatic zones: the mountain zone located over 2000 meters above sea level and that covers $150 \mathrm{~km}^{2}$ ( $9 \%$ of the area); and the highland zone that lies between 1500 to 2000 meters above sea level covers over $1600 \mathrm{~km}^{2}$ (91\% of the area). The average annual rainfall is $839 \mathrm{~mm}$. Mean minimum and maximum temperature are $8^{\circ} \mathrm{C}$ and $28.0^{\circ} \mathrm{C}$; respectively. The mean temperature at the time of this study in 2009 was $18.5^{\circ} \mathrm{C}$. The dominant soil is vertisol, which is fertile but poorly drained and difficult to work on [14].

The district is best suited to diverse agricultural production systems, both for intensive and extensive agriculture. Teff (Eragrostis tef) and wheat are the two major crops growing in the district in addition to pulses. Most farmers rotate chickpeas with cereals for soil fertility and resting of the land. Livestock production is an integral part of the whole agricultural production system.

\subsection{Research Design}

The study conducted in May and June, 2009 as a part of $\mathrm{PhD}$ thesis research of this paper's corresponding author. The study focused both on biological and socio-economic data. The biological study used to target manure sampling to assess different nutrients lost due to manure storage and age, and their impact on the environment. The biological data were then compromised through the interview of the manure owners.

\subsubsection{Biological study}

Heaps of manure were identified from farmers backyard visited during the study period and manure were classified according to the size, age and storage condition as described by Tadesse et al [24]. A total of 25 samples were taken. The storage condition was classified as shaded, open and fresh (without a heap) as shown in table 1 below. Sample manure was scooped from four random spots on each heap at different height of $0-50 \mathrm{~cm}, 50-100 \mathrm{~cm}$ and above $100 \mathrm{~cm}$ to a depth of about $30 \mathrm{~cm}$. The four sub samples from each representative height $(0-50 \mathrm{~cm}, 50-100 \mathrm{~cm}$ and above $100 \mathrm{~cm})$ of the manure heap were separately pooled and a sample of approximately $1 \mathrm{~kg}$ was taken and stored in plastic bags for each height before chemical analysis. The pooled samples for each height were air dried and ground to pass through a 2 $\mathrm{mm}$ screen ready for further analysis based on guidelines prepared by Tadesse et al [24].

Table 1. Sampled manur storage condition, heap height and storage age

\begin{tabular}{|c|c|c|c|c|}
\hline $\begin{array}{c}\text { Storage } \\
\text { condition }\end{array}$ & $\begin{array}{c}\text { Heap } \\
\text { height } \\
(\mathrm{m})\end{array}$ & $\begin{array}{c}\text { Storage } \\
\text { age (yrs) }\end{array}$ & Frequency & $\begin{array}{c}\text { Feed } \\
\text { management }\end{array}$ \\
\hline Shaded & $1.0-1.5 \mathrm{~m}$ & $1.0-3.0$ & 6 & $\begin{array}{c}\text { Indigenous } \\
\text { animals with } \\
\text { straw feeding } \\
\text { and } \\
\text { supplementation }\end{array}$ \\
\hline Shaded & $1.5-2.0 \mathrm{~m}$ & $>3.0$ & 4 & as above \\
\hline Open & $0-0.50 \mathrm{~m}$ & $0.5-1.0$ & 1 & as above \\
\hline Open & $0.50-1 \mathrm{~m}$ & $0.5-\mathrm{I} .0$ & 9 & as above \\
\hline Open & $1-1.5 \mathrm{~m}$ & $0.5-1.0$ & 2 & as above \\
\hline Fresh & 0 & 0 & 3 & as above \\
\hline
\end{tabular}

Key: Storage condition: Shaded mean manure heap covered by grass, mud or plated by manure itself; Open mean uncovered or not protected from sun and rain. Fresh manure means those collected within 12 hours of dropping. 


\subsubsection{Manure Chemical Analysis}

Total nitrogen was determined by the micro Kjedalhl digestion, distillation and titration method described in the manual of Tadesse et al [24]. Total phosphorus and potassium was determined by dry ash method as described by Tadesse et al [24]. Organic carbon was analyzed using method as described in the manual of the above authors[24]. The dry matter content of the manure was obtained by oven drying the 25 samples at the $105^{\circ} \mathrm{C}$ for $24 \mathrm{hrs}$. The carbon nitrogen ratio was computed by dividing the amount of carbon by that of nitrogen. Calculations were made on dry matter basis.

\section{Methane $\left(\mathrm{CH}_{4}\right)$}

Methane emissions per household were calculated for cattle, sheep, goats, horses, mules and donkeys using the average number of animals owned by household; according to the inventory methodology from the IPCC [13].

\section{ECH4 (kg/year) \\ $=f \mathrm{CH} 4(\mathrm{~kg} / \mathrm{head}$ \\ /year) $x P$ (average number of animals)}

Where; ECH4 (Gg/year) = Emissions, f CH4 $(\mathrm{kg} /$ head$/$ year $)=$ Emission factor, and

$\mathrm{P}=$ Average number of animals. Owned by households

Nitrous oxide emission: The IPCC uses the emission factors of equines, sheep, goats, poultry and cattle, to calculate their $\mathrm{N}_{2} \mathrm{O}$ emissions as follows: Nitrous oxide $=N$ X EF

Where; $\mathrm{N}_{2} \mathrm{O}=$ emissions from the animals ( $\mathrm{kg} \mathrm{N} /$ year),

$\mathrm{N}=$ number of animals, and

$\mathrm{EF}=\mathrm{N}_{2} \mathrm{O}$ emission factor $\left(\mathrm{kg} \mathrm{N}_{2} \mathrm{O}-\mathrm{Nper}\right.$ animal $)$.

The emission factor (EF) is a function of the nitrogen excretion from the animal [13] and the waste management system in the region [13]. The $\mathrm{N}_{2} \mathrm{O}$ emission factors of sheep and goats as well as equines were estimated by averaging them. The default values from the IPCC [13] were used to calculate the EF.

Carbon release: The amount of carbon released from manure burning per household was adapted from IPCC [13] a formula which was used to estimate carbon emission from burning of crop residues as follows:

Carbon (kg emission per day) $=$

Manure carbon fraction $x$ manure DM fraction $x$ Total DM manure burnt per day

\subsection{Statistical and Mathematical Analysis}

For both socioeconomic and chemical analyses SPSS Version 17.0.1 [23] was used for statistical interpretation. Greenhouse gas emissions from manure were estimated using mathematical formulae described by the IPCC [13] indicated as follows.

\section{Result and Discussion}

\subsection{Nutrient Losses and Manure Management}

Comparisons were made for $\mathrm{N}$ (Nitrogen), $\mathrm{P}$ (Phosphorous), K (Potassium) and OM (Organic Matter) based on different manure management systems such as manure heaps based on the following criteria; manure heap covering, age of manure and height of manure heaps. According to Hansen et al [8] covering of manure in storage reduces the loss of carbon, ammonia $\mathrm{N}$ and production of greenhouse gases. However, in the current study manure heaps which were exposed to external environment had an average of $1.4 \pm 0.3 \% \mathrm{~N}$ content while covered manure had $1.2 \pm 0.7 \% \mathrm{~N}$. In general, N, P and K values were higher for manure stored in the open than that was covered. The analysis of variance showed a significant $(\mathrm{P}<0.05)$ difference between covered and open manure heaps for $\mathrm{N}, \mathrm{P}$ and $\mathrm{K}$. The difference was due to age disparity between open and covered manure. The samples from open manure heaps were those between the age of 6 to 8 months, while covered manure heaps were above one year in storage. This indicated that the longer the storage age the higher the nutrient loss through emissions, leaching, decomposition and physical weathering [26].

Long storage periods of (slurry) manure and high temperatures increased $\mathrm{C}$ (carbon) and $\mathrm{N}$ losses, depending on storage conditions [6]. Harris and Yusuf [9] reported N losses of up to $59 \%$ in Ghana during three months of storage of the manure. A comparison of manure based on the storage age that is shown in table 2 below indicated that with increasing age the nutrient depletion for N, P, K increased, particularly the $\mathrm{N}$ loss rate was higher than the other two nutrients due to the volatile nature of $\mathrm{N}[16,22]$.

In the current study the highest loss of $\mathrm{N}, \mathrm{P}$ and $\mathrm{K}$ occurred in the years 2 to 3 at the rate of $84 \%, 19 \%$ and $42 \%$; respectively. The analysis of variance at $\mathrm{P}<0.05$, there was a significant difference in storage age for $\mathrm{N}$ and $\mathrm{K}$, but there was no significant difference for $\mathrm{P}$. The current findings agree with the results obtained elsewhere [18,26] who reported that $\mathrm{N}$ loss during (aerobic) composting varied from about 20 to $80 \%$. These authors also reported that losses were by far the highest for nitrogen, followed by potassium and phosphorus which agreed with the current findings. Therefore, storage of manure for more than two years has a serious environmental impact on nitrogen, which is lost in the form of ammonia, nitrates and nitrous oxide [2]. Refer to table 2 below. 
Table 2. Chemical composition of different storage type, storage age and heap height

\begin{tabular}{|c|c|c|c|c|c|c|c|c|c|c|c|}
\hline \multirow[b]{2}{*}{ Composition } & \multicolumn{2}{|c|}{ Manure shade } & \multicolumn{5}{|c|}{ Storage age } & \multicolumn{4}{|c|}{ Heap height } \\
\hline & Covered & Uncovered & Fresh & 6-12 mo & $1-2 \mathrm{yrs}$ & $\begin{array}{l}2-3 \\
\text { yrs }\end{array}$ & $>3 \mathrm{yrs}$ & $\begin{array}{c}0-0.5 \\
\mathrm{~m}\end{array}$ & $\begin{array}{c}0.5-1 \\
.0 \mathrm{~m} \\
\end{array}$ & $\begin{array}{c}1-1.5 \\
\mathrm{~m}\end{array}$ & $\begin{array}{l}1.5- \\
2 \mathrm{~m}\end{array}$ \\
\hline $\mathrm{DM} \%$ & $97.8 \pm 0.8$ & 97.2 & $81.84 \pm 6.2$ & $97.2 \pm 0.4$ & $97.1 \pm 0.3$ & 96.2 & $96.4 \pm 1.8$ & 96.5 & 97.2 & 96.9 & 97.6 \\
\hline OM\%Kg DM & $36.3 \pm 10.3$ & $36.6 \pm 10.5$ & 76.2 & $36.6 \pm 10.5$ & $32.1 \pm 7.6$ & 30.8 & $45.0 \pm 2.1$ & 55.1 & 50.4 & 49.0 & 33.2 \\
\hline N \% Kg DM & $1.2 \pm 0.7$ & $1.4 \pm 0.3$ & $1.9 \pm 0.07$ & $1.4 \pm 0.3$ & $1.4 \pm 0.9$ & 0.3 & 1.2 & 1.7 & 1.4 & 1.9 & 1.6 \\
\hline P ppm & $1.4 \pm 0.3$ & $1.6 \pm 0.3$ & $1.6 \pm 0.4$ & $1.6 \pm 0.3$ & $1.4 \pm 0.1$ & 1.6 & $1.3 \pm 0.4$ & 2.3 & 1.9 & 1.8 & 1.8 \\
\hline $\mathrm{K} \% \mathrm{~kg} \mathrm{DM}$ & $0.56 \pm 0.2$ & $0.56 \pm 2$ & $0.72 \pm 0.01$ & $0.56 \pm 0.2$ & $0.71 \pm 0.12$ & 0.59 & $0.41 \pm 0.1$ & 0.49 & 0.19 & 0.58 & 0.69 \\
\hline
\end{tabular}

Storage age showed significant differences in chemical composition like OM, too[18]. For example; the organic matter content was higher for fresh manure $(76 \%)$ compared to 6 to 12 months old manure ( $36 \%$ ). The difference of about $40 \%$ in organic matter between fresh manure and 6 to 12 months old manure could be attributed to weathering. This finding is in agreement with the review reported by Kulling et al [16] who said that average carbon losses of about $40 \%$ were suggested for solid cattle manure, but the value could vary as a result of storage conditions (aeration, storage period and temperature), and manure characteristics (degradability and moisture content), that strongly affected organic matter degradation and carbon loss. In the current study the losses in organic matter and other nutrients increased with increasing age of manure as shown in table 2 .

The other argument of manure management that affected nutrient depletion was the height of the manure heaps. Petersen et al [21] reported that losses of K, OM and $\mathrm{N}$ were much higher for heap storage, with large differences for manure from rations with high protein content. In the current study most farmers $(80 \%)$ stored manure in heaps while $2 \%$ of them used deep litter storage. Heap heights of up to $2 \mathrm{~m}$ were recorded in the study area. The analysis of variance for manure height at $\mathrm{P}<0.05$ showed no significant difference in chemical composition because of heap height. This could be attributed due to the fact that the upper heap tips are well protected from weathering, whereas lower layers were enriched by nutrients leaching from the upper layers, which made the nutrient composition uniform across different heap heights, as shown on table 2 .

\subsection{Manure Management and Environment}

Variations in nutrient loss during manure collection, storage or processing and application was high [16,22]. The most important processes involved in the loss of nutrients were: leaching of soluble nutrients from urine in particular N, $\mathrm{K}$ and $\mathrm{S}$ (Sulfur), and Gaseous losses during collection, storage and application in particular ammonia.

Manure management systems in the study area were affected by livestock husbandry practices. Only crossbred cattle (5\% of total herd) were zero grazed. Indigenous cattle were taken out to grazing in the fields during the day and kept in kraals at night. Kraals were permanently kept near homesteads to avoid theft. Therefore, there was a substantial loss of nutrients during the day as the animals goes out for grazing in the fields. The losses are very high through urine, because urine patches contained as much as 200 to $550 \mathrm{~kg}$ $\mathrm{N} / \mathrm{ha}$ [26].Volatilization of $\mathrm{N}$ might also be considerable (10 - 25\%) since most of cattle dung was collected from the fields by poor farmers who did not have enough cattle to produce manure [18]. A nitrogen loss of $41 \%$ from dung was reported other researchers during the collection of cattle dung for 144 days and composting [18].

Part of the nutrients in dung was also lost through leaching and surface runoff, due to trampling and poor drainage in the kraals [9]. Volatilization losses were dependent on the level of ventilation, depth of storage tanks and storage time [6] and often ranged between 5 and $35 \%$ of the total $\mathrm{N}$ excreted.

\subsubsection{Livestock greenhouse gas emissions in households}

Estimates of methane emissions and manure from cattle, sheep, goats, horses, mules and donkeys and nitrous oxide emissions were calculated based on IPCC [13] green house gasses emission guidelines and average household livestock ownership in 2009 data which was obtained through socioeconomic survey ( Table 3 below). The emissions were calculated as: the emission factor per animal multiplied by the number of animals in a household. The emission factors were based on the IPCC data [13]. These emissions were important in evaluating the contribution of livestock to the greenhouse gases in the atmosphere. Table 3 below shows the concentration of methane and nitrogen contributed by an average household in the study area.

Table 3. Average methane and nitrogen emissions per household

\begin{tabular}{|c|c|c|c|c|c|}
\hline \multirow{2}{*}{$\begin{array}{c}\text { Livestock } \\
\text { species }\end{array}$} & \multirow{2}{*}{$\begin{array}{c}\text { Household } \\
\text { average } \\
\text { holding }\end{array}$} & \multicolumn{3}{|c|}{ Methane kg/yr } & Emissions \\
\cline { 4 - 6 } & $\begin{array}{c}\text { Manure } \\
\text { Produced }\end{array}$ & Total & $\begin{array}{c}\text { from } \\
\text { manure } \\
\text { kg/yr }\end{array}$ \\
\hline Cattle & 8.3 & 265.6 & 8.3 & 273.9 & 318.72 \\
\hline $\begin{array}{c}\text { Sheep } \\
\text { and goats }\end{array}$ & 4.3 & 21.5 & 0.73 & 11.2 & 46.44 \\
\hline Equines & 2.1 & 29.4 & 2.67 & 32.1 & 83.16 \\
\hline Poultry & 7.6 & - & 0.14 & 0.14 & 3.78 \\
\hline Total & & 316.5 & 11.84 & 328.3 & 452.1 \\
\hline
\end{tabular}




\section{(I). Methane $\left(\mathrm{CH}_{4}\right)$}

The global atmospheric concentration of $\mathrm{CH}_{4}$ has increased from a pre-industrial value of about $715 \mathrm{ppb}$ to 1 $732 \mathrm{ppb}$ in the early 1990s, and $1774 \mathrm{ppb}$ in 2005 [11]. The growth rate has declined since the early 1990s, consistent with total emissions (sum of anthropogenic and natural sources) and nearly constant during that period. One of the most important sources of anthropogenic methane is ruminants. They produce methane during the normal enteric fermentation process. In the $1990 \mathrm{~s}$, the ruminants were thought to be responsible for about $28 \%$ of all anthropogenic $\mathrm{CH}_{4}$ emissions [17,19].

In the current study the amount of $\mathrm{CH}_{4}$ produced was estimated at $328.3 \mathrm{~kg}$ per year per household and depending on the type of animal. The most important ruminants in terms of $\mathrm{CH}_{4}$ emissions were cattle which produced $82 \%$ of the household emissions. The emissions of 1 million metric tons of $\mathrm{CH}_{4}$ are equivalent to the emissions of 25 million metric tons of carbon dioxide called "equivalent carbon dioxide" $\left(\mathrm{CO}_{2} \mathrm{e}\right)$. This is the concentration of $\mathrm{CO}_{2}$ that could cause the same level of radioactive force and concentration of greenhouse gases. Therefore, the current amount of $\mathrm{CH}_{4}$ produced per household was estimated at 8.2 tons $\mathrm{CO}_{2} \mathrm{e}$ per household per annum. The reference value adopted the emission factor per animal were taken from IPCC [13] which has an uncertainty of $20 \%$ in these values. The average household size in the current study was 6.2 , thus the amount of $\mathrm{CO}_{2} \mathrm{e}$ methane emission per capita per year was 1.3 tons. This rate alone was $30 \%$ higher than the total $\mathrm{CO}_{2} \mathrm{e}$ for all GHG emissions reported in Ethiopia, 1 ton per capita reported in 2005 [27].

\section{(II). Nitrous oxide $\left(\mathrm{N}_{2} \mathrm{O}\right)$}

It was estimated that the global atmospheric concentration of $\mathrm{N}_{2} \mathrm{O}$ increased from pre-industrial value of about $270 \mathrm{ppb}$ to $319 \mathrm{ppb}$ in 2005 [11]. In 1998 the $\mathrm{N}_{2} \mathrm{O}$ emissions from manure management systems were responsible for $26 \%$ of the total anthropogenic emissions of $\mathrm{N}_{2} \mathrm{O}[10,15]$. The study area $\mathrm{N}_{2} \mathrm{O}$ emissions from domestic livestock were calculated using the average livestock ownership of respondent households, and the inventory data obtained by IPCC [13].

Therefore, the $\mathrm{N}_{2} \mathrm{O}$ released per household was estimated as $\quad 452.1(N) \times 0.02(E F)=9.04 \mathrm{~kg} \quad \mathrm{~N}_{2} \mathrm{O}$ emissions/annum/household. The emissions of 1 million metric tons of $\mathrm{N}_{2} \mathrm{O}$ were equivalent to the emissions of 298 million metric tons of carbon dioxide. In the current study, the $\mathrm{CO} 2$ equivalent of $\mathrm{N}_{2} \mathrm{O}$ emitted through various manure inappropriate management systems was 2694 $\mathrm{kg} /$ annum/household or 0.4 ton per capita per year..

(iii) Carbon (C)

About $94 \%$ of the respondents in the current study used manure for cooking fuel as shown in table 1 above. When manure was burnt directly, most of the organic compounds such as $\mathrm{C}, \mathrm{N}$ and $\mathrm{S}$ were lost to the atmosphere, which contributed to greenhouse gas emissions [5] and other nutrients were recycled on arable land through the application of the ashes in the fields.

Eighty percent $(80 \%)$ of the respondents said that they used manure aged between 6 to 12 months for cooking. Therefore, the carbon fraction of 6 to 12 months old manure was $36.6 \% \mathrm{OM}$. Assuming there was $55 \% \mathrm{C}$ in the $\mathrm{OM}$ manure [8] and at carbon factor of 0.2013 the DM fraction was 0.972 .. The average amount of manure burnt per day for 3 years as reported in the current study was 1.57 $\mathrm{kg} / \mathrm{day} /$ household. Thus, the annual carbon emitted per household due to manure burning was calculated as:

$$
\begin{gathered}
\mathrm{C}(\mathrm{kg} \text { emissions } / \text { household } / \text { year })= \\
0.2013 \times 0.972 \times 1.57 \mathrm{~kg} / \text { day } \times 365.25 \text { days } \\
=112.20 \mathrm{~kg} \text { carbon emitted /household } / \text { year }
\end{gathered}
$$

It was also estimated that the global atmospheric concentration of $\mathrm{CO}_{2}$ increased from a pre-industrial value of about $280 \mathrm{ppm}$ to $379 \mathrm{ppm}$ in 2005. The annual $\mathrm{CO}_{2}$ concentration growth rate was larger from 1995 to 2005, (an average of $1.9 \mathrm{ppm} /$ year) than it has been since the beginning of the continuous direct atmospheric measurements from 1960 to 2005 , (an average of $1.4 \mathrm{ppm} /$ year), with year-to year variability in the growth rates [27]. To convert carbon to carbon dioxide, a factor of 3.67 (i.e. 44/12) was used [13]. Therefore, the amount of carbon dioxide released per household from burning of manure was $122.20 \mathrm{~kg} \mathrm{C} \mathrm{x} 3.67=$ $381.48 \mathrm{~kg} \mathrm{CO}_{2} /$ household. The world $\mathrm{CO}_{2}$ emissions per capita per annum in 2006 were estimated at $4180 \mathrm{~kg} \mathrm{CO}_{2}$ [11].

Thus, with an average of 6.2 family size of in the current study area per capita $\mathrm{CO}_{2}$ emission was estimated at $61.50 \mathrm{~kg}$ $\mathrm{CO}_{2}$. In the USA, which is the highest carbon emitter, $\mathrm{CO}_{2}$ emissions per capita from human activities in 2006 was estimated at18 $600 \mathrm{~kg} \mathrm{CO}_{2}$ [11]. The comparison showed that the use of manure as fuel in the study area had no significant effect on $\mathrm{CO}_{2}$ emissions per capita, but they had a negative impact in terms of nutrient cycling, soil carbon sequestration and soil fertility. Therefore, for improved yield and healthy eco-systems balance, manure burning has to be substituted by other alternative energy sources such as bio-gas [6].

In general, livestock and manure management systems contributed a lot to greenhouse gas emissions. The total carbon equivalent $\left(\mathrm{CO}_{2} \mathrm{e}\right)$ gas emitted per household per annum by livestock, manure management and burning was estimated at $11,276 \mathrm{~kg} \mathrm{CO}_{2}$ e (i.e. $8200 \mathrm{~kg} \mathrm{CO}_{2} \mathrm{e}$ from methane and manure plus $2694 \mathrm{CO}_{2} \mathrm{e}$ from $\mathrm{N}_{2} \mathrm{O}$ emissions from manure management and $381.48 \mathrm{~kg} \mathrm{CO}$ e from $\mathrm{CO}_{2}$ from manure burning) that is about 2 tons $\mathrm{CO}_{2} \mathrm{e}$ per capita per year, twice reported by Wikipedia [27] for Ethiopia emission in 2005. Had other anthropogenic and natural greenhouse gases emitted by household been added to the current carbon equivalent value, the amount of carbon equivalent gases released per household in Ethiopia would be more alarming. This calls for more research to estimate greenhouse gas emissions at household level under the 
smallholder production systems. The largest carbon equivalent emissions were from methane $(72.6 \%)$, nitrous oxide (24\%) and Carbon dioxide (3.4\%) which showed that there is an urgent need to improve livestock and manure management systems under smallholders' agriculture.

In 1998 , Ethiopia ranked $18^{\text {th }}$ globally in terms of $\mathrm{CH}_{4}$ emissions from livestock and $10^{\text {th }}$ in $\mathrm{N}_{2} \mathrm{O}$ emissions from manure management. The ranking in $\mathrm{N}_{2} \mathrm{O}$ emissions went down from $13^{\text {th }}$ in 1980 s to $10^{\text {th }}$ in 1998 [28]. This evidence showed that due attention should be given to reduce $\mathrm{N}_{2} \mathrm{O}$ emissions by improving manure management at local level particularly at farm level.

\section{Conclusions}

Manure management systems in the study area were affected by the livestock husbandry practices. Only crossbred cattle (5\% of total herd) were zero- grazed. Indigenous cattle grazed out in the fields during the day and at night they were kept in kraals established near homesteads. There was a substantial loss of nutrients during the day when animals were grazing in the fields through leaching and trampling of dung and urine patches. Therefore, indoor or zero grazing of livestock could reduce nutrient losses.

Comparisons showed that the use of manure as fuel in the study area had no significant effect on $\mathrm{CO}_{2}$ emissions at household and local level, but had a negative impact on soil carbon storage and soil fertility. Therefore, for improved yield and healthy eco-systems balance manure burning has to be substituted by other alternative energy sources such as bio-gas, firewood and kerosene.

The largest carbon equivalent emissions were from methane $(72.6 \%)$, nitrous oxide $(24 \%)$ and carbon dioxide (3.4\%) which indicated the need to improve livestock and manure management systems under smallholder agriculture. Existing mitigation strategies for methane emissions for dairy, e.g., the addition of ionophores, fats, use of high quality forages, and increased use of grains were the recommended management practices to be exercised to reduce emission. Recently a new dietary strategy was proposed in the developed world to reduce $\mathrm{CH}_{4}$ emissions from ruminants such as by manipulating ruminant fermentation directly by inhibiting methanogens and protozoa or by diverting hydrogen ions away from methanogens. In developing world; change in feeding systems, breed selection, good animal husbandry and improved take-off were identified as viable options to reduce greenhouse gas emissions.

\section{Conflict of Interest}

The authors declare that there are no conflicts of Interest.

\section{Acknowledgements}

We gratefully acknowledge (ILRI) International Livestock Research Institute for the research support.

\section{REFERENCES}

[1] Asres, K., 2003. Impact of incentive system on soil and water conservation activities in Ambasel Area, South Wollo, Ethiopia, MSc. Thesis, Alemaya University, pp 104

[2] Brandjes, P.J., de Wit, J., van der Meer, H.G., 1996. Environmental Impact of Animal Manure Management, $\mathrm{H}$. Van Keulen International Agriculture Centre, Wageningen, The Netherlands.

[3] deHann, C.H., Steinfeld, H., Blackburn, H., 1997. Livestock and the environment: Finding a balance, Suffolk, UK, WRENmedia.

[4] Food and Agricultural Organization of the United Nations(FAO), 2006. Livestock's Long Shadow: environmental issues and options, LEAD website: http://www.virtual centre.org/en/dec/toolbox/homepage.htm/ Viewed on 08 March 2013

[5] Food and Agricultural Organization, 2002. Harvesting carbon sequestration through land-use change: A way out of rural poverty?In: The state of food and agriculture, Rome, $\mathrm{ftp} / / / \mathrm{ftp}$.fao.org/docrep/fao/004/y6000e/y6000e10.pdf. Viewed on $08 / 03 / 2013$

[6] Food and Agricultural Organization,2001. Soil carbon sequestration for improved land management. Food and Agricultural Organization, World Soil Resources Report No. 96.b Rome, ftp://ftp.fao.org/agl/agll/docs/wsrr96e.pdf Viewed on 8 March 2013

[7] Getenet, A., 2003. Effect of manure and nitrogen fertilization on the establishment, herbage yield and seed productivity of perennial grasses, Challenges and opportunities in livestock marketing in Ethiopia, Ethiopian Society of Animal Production, Addis Abeba (Ethiopia). Addis Ababa (Ethiopia): ESAP, 2003. 10. In Proceedings of the Annual Conference of Ethiopian Society of Animal Production, Addis Ababa (Ethiopia), 21-23 Aug 2003.- p. 245-253

[8] Hansen, M.N., Henriksen ,K., Sommer, S.G., 2006. Observations of production and emission of greenhouse gases and ammonia during storage of solids separated from pig slurry: effects of covering. Atmos. Environ. 40, pp 4172-4181.

[9] Harris , F., Yusuf, M.A., 2001, Manure Management by Smallholders Farmers in The Kano Close-settled Zone, Nigeria. Expl Agric. volume 37, Cambridge University Press pp. $319 \pm 332$

[10] Hickmen, J.E., Havlikova, M., Kroeze, C., Palm, C.A., 2011. Current and future nitrous oxide emissions from African agriculture. Current opinion in Environmental Sustainability, 2011, 3: 370-378

[11] Intergovernmental Panel for Climate Change( IPCC), 2007. Climate Change 2007: Synthesis Report, Contribution of 
Working Groups I, II and III to the Fourth Assessment Report of the Intergovernmental Panel on Climate Change, Core Writing Team, Pachauri, R.K. and Reisinger, A. (Eds.) IPCC, Geneva, Switzerland. pp 104

[12] Intergovernmental Panel for Climate Change( IPCC) 2001. Climate change 2001: Impacts, adaptation and vulnerability, IPCC Third Assessment Report. UK, Cambridge University Press.1032pp.

[13] Intergovernmental Panel for Climate Change( IPCC), 1996. Revised 1996, IPCC Guidelines for National Greenhouse Gas Inventories, IPCC, Mexico City.

[14] Improving Productivity and Market Success for Ethiopian Farmers(IPMS) 2004. Ada Liben Woreda Diagnostic Survey, ILRI (International Livestock Research Institute), Addis Ababa, Ethiopia.

[15] Kroeze, C., Mosier, A., 2002. Progress in source strength estimates of nitrous oxide (N2O). In (eds. Van Ham, J; Baede, A.P.M.; Guicherit, R.; Williams-Jacobse, J.G.F.M.) NON-CO2 Greenhouse gases: Scientific understanding, control options and policy aspects. Proceedings of the Third International Symposium. Maastricht, The Netherlands 21-23 January 2002. Pp XXIX-XXXIII.

[16] Külling, D.R., Menzi, H., Sutter, F., Lischer, P., Kreuzer, M., 2003. Ammonia, nitrous oxide and methane emissions from differently stored dairy manure derived from grass-and hay-based rations. Nutri. Cycl. Agroecosyst. 65: 13-22

[17] Kurihara, M., Nishida, T., Purnomoadi,A., Shibata, M., Terada, F., 2002. The prediction of methane conversion rate from dietary factors In: Greenhouse Gases and Animal Agriculture. (Ed. J. Takahashi and B. A. Young), Elsevier, Amsterdam. pp. 171-174.

[18] Lekasi, J. K., Tanner, J.C., Kimani, S.K., Harris, P.J.C., 1998. Manure management in the Kenya Highlands: Practices and potential. Natural Resources Systems Programme, Department for International Development and Henry Doubleday Research Association, UK.

[19] Moss, A.R., Jouany, J.P., Newbold, J., 2000. Methane production by ruminants: Its contribution to global warming. Ann. Zootech. 49, 231-253.

[20] National Meteorological Services Agency of Ethiopia (NMSA ),2001. Initial National Communication of Ethiopia (INCE) to the UNFCCC, NMSA, June 2001

[21] Petersen, S.O., Lind, A.M., Sommer, S.G., 1998. Nitrogen and organic matter losses during storage of cattle and pig manure. Journal of Agricultural Science Cambridge 130, 6979

[22] Rotz, C.A. 2004. Management to reduce nitrogen losses in animal production. Journal of Animal Science, 82(E.Suppl.), E119-E137.

[23] SPSS (Statistical Package for Social Sciences). 2008. SPSS version 17.0.1 for windows. SPSS Inc., U.S.A.

[24] Tadesse, T., Haque, T., Aduayi, E.A., 1991. Soil, plant, water, fertilizer, animal manure \& compost analysis manual, ILCA PSD Working Document;B13, ILCA( International Livestock Center for Africa), Addis Ababa, Ethiopia

[25] Tesfaye,K., Madsen, J.O., Tegegne, A., 2004. Manure Production, handling and use around Holetta Agricultural Research Center: In Proceeding of the Conference of Ethiopian Society of Animal Production( ESAP), 25-27 August 2004, Addis Ababa Ethiopia. ESAP pp 3-11.

[26] Tittonell, P., Rufino, M.C., Janssen, B.H., Giller, K.E., 2010. Carbon and nutrient losses during manure storage under traditional and improved practices in smallholder crop-livestock systems-evidence from Kenya, Plant and Soil (2010). Volume: 328, Issue: 1-2, Pages: 253-269

[27] Wikipedia. 2011. List of countries by green house gas emission.

en.wikipedia.org/.../List_of_countries_by_greenhouse_gas_e missions Viewed 6 April 2013.

[28] World Resources Institute, Climate Analysis Indicators Tool (WRI, CAIT). 2012. CAIT version 9.0. Washington, DC: World Resources Institute. Available online at: http://cait.wri.org. Viewed on 16 April 2013 